\title{
PCR-Mediated Detection and Quantification of the Goss's Wilt Pathogen Clavibacter michiganensis subsp. nebraskensis Via a Novel Gene Target
}

\author{
R. Ryan McNally, Carol A. Ishimaru, and Dean K. Malvick
}

First, second, and third authors: Department of Plant Pathology, University of Minnesota, St. Paul 55108; and second and third authors: Stakman-Borlaug Center for Sustainable Plant Health, University of Minnesota. Accepted for publication 14 July 2016.

\begin{abstract}
McNally, R. R., Ishimaru, C. A., and Malvick, D. K. 2016. PCR-mediated detection and quantification of the Goss's wilt pathogen Clavibacter michiganensis subsp. nebraskensis via a novel gene target. Phytopathology 106:1465-1472.

Goss's leaf blight and wilt of maize (corn) is a significant and reemerging disease caused by the bacterium Clavibacter michiganensis subsp. nebraskensis. Despite its importance, molecular tools for diagnosing and studying this disease remain limited. We report the identification of CMN_01184 as a novel gene target and its use in conventional PCR (cPCR) and SYBR green-based quantitative PCR (qPCR) assays for specific detection and quantification of $C$. michiganensis subsp. nebraskensis. The cPCR and qPCR assays based on primers targeting CMN_01184 specifically amplified only $C$. michiganensis subsp. nebraskensis among a diverse collection of 129 bacterial and fungal isolates, including multiple maize

bacterial and fungal pathogens, environmental organisms from agricultural fields, and all known subspecies of $C$. michiganensis. Specificity of the assays for detection of only $C$. michiganensis subsp. nebraskensis was also validated with field samples of $C$. michiganensis subsp. nebraskensis-infected and uninfected maize leaves and C. michiganensis subsp. nebraskensis-infested and uninfested soil. Detection limits were determined at 30 and $3 \mathrm{ng}$ of pure C. michiganensis subsp. nebraskensis DNA, and 100 and $10 \mathrm{CFU}$ of C. michiganensis subsp. nebraskensis for the cPCR and qPCR assays, respectively. Infection of maize leaves by C. michiganensis subsp. nebraskensis was quantified from infected field samples and was standardized using an internal maize DNA control. These novel, specific, and sensitive PCR assays based on CMN_01184 are effective for diagnosis of Goss's wilt and for studies of the epidemiology and host-pathogen interactions of C. michiganensis subsp. nebraskensis.
\end{abstract}

Clavibacter michiganensis subsp. nebraskensis is the causative agent of Goss's leaf blight and wilt (commonly known as Goss's wilt), a destructive and spreading disease of maize (Zea mays subsp. mays). Symptoms include leaf blight and systemic vascular wilt. The leaf blight develops as long lesions that extend parallel to veins and exhibit irregular, dark, water-soaked spots or 'freckles' (Jackson et al. 2007). Yield losses due to Goss's leaf blight and wilt exceeding $50 \%$ have been reported for susceptible hybrids (Jackson et al. 2007; Jardine and Claflin 2016).

Goss's wilt of maize was first identified in the United States in 1969 in Nebraska (Vidaver and Mandel 1974; Wysong et al. 1973). The disease persisted as a sporadic regional issue in Nebraska and bordering states in the following decades (Jackson et al. 2007; Vidaver et al. 1981). More recently, since about 2006, the incidence and severity of Goss's wilt has increased in Nebraska, and the geographic distribution has expanded greatly in the United States and Canada. While factors responsible for this increase remain speculative, to date 16 states and two Canadian provinces have reported Goss's wilt (Friskop et al. 2014; Howard et al. 2015; Korus 2011; Malvick et al. 2010; Ruhl et al. 2009; Singh et al. 2015, Tambong et al. 2015; Wysong et al. 1981). Consequently, Goss's wilt of maize is considered a reemerging and spreading disease of considerable economic importance (Jackson et al. 2007).

The recent increase in Goss's wilt as an economically important disease in North America highlights a need for improved and widely accessible methods for rapid and accurate disease diagnosis and pathogen-specific detection. Diagnosis of Goss's wilt has historically been based on the presence of typical disease symptoms

Corresponding author: D. K. Malvick; E-mail address: dmalvick@umn.edu on leaves and signs of bacterial infection, such as bacterial ooze. Symptoms caused by several other common bacterial and fungal maize diseases can be confused with Goss's wilt. Reported techniques for detection of $C$. michiganensis subsp. nebraskensis include isolation on semiselective media, DNA and protein fingerprinting, a quantitative polymerase chain reaction (qPCR) assay that requires a TaqMan probe, and nonspecific serological assays (Bach et al. 2003; Gross and Vidaver 1979; Korus 2011; Lee et al. 1997; Louws et al. 1998; Pastrik and Rainey 1999; Smidt and Vidaver 1986; Zaluga et al. 2011). Recently, a loop-mediated isothermal PCR (LAMP) assay was developed for specific detection of $C$. michiganensis subsp. nebraskensis in maize (Yasuhara-Bell et al. 2016). This LAMP assay provides a rapid means of pathogen detection; however, it is not quantitative and LAMP assays are currently used less commonly in diagnostic and research laboratories than other PCR-based assays.

PCR techniques have proven to be powerful and readily accessible methods for detection, identification, quantification, and diagnosis of bacterial and other plant pathogens and diseases (Schaad and Frederick 2002; Vincelli and Tisserat 2008). Conventional PCR (cPCR) is simple, fast, specific, doesn't require expensive equipment, and eliminates the need for selective media or culturing of an organism to confirm its presence. Real-time qPCR generally has high sensitivity, allows for enumeration, requires no gel analysis, has high throughput potential, and can specifically detect multiple different organisms simultaneously in one test (Bilodeau 2011; McCartney et al. 2003; Mumford et al. 2006; Schaad and Frederick 2002; Vincelli and Tisserat 2008). qPCR can accurately determine the copy number of a specific target gene or DNA molecule from a bacterial or fungal species, which can be correlated to microbial number or population (Gachon and Saindrenan 2004; Schaad and Frederick 2002; Schroeder et al. 2006; Vincelli and Tisserat 2008).

To date, methods for specific detection and quantification of C. michiganensis subsp. nebraskensis have not been reported that 
allow use of cPCR or qPCR not requiring expensive TaqMan probes for qPCR, two criteria that make assays readily accessible and adoptable for many laboratories. A challenge in developing specific assays has been the fact that $C$. michiganensis subsp. nebraskensis is one among eight closely related subspecies of $C$. michiganensis pathogens affecting a wide diversity of crops, (Eichenlaub and Gartemann 2011). The genetic relatedness within the species has made accurate and specific detection of $C$. michiganensis subsp. nebraskensis difficult (González and Trapiello 2014; Korus 2011; Yasuhara-Bell et al. 2016). We recognized the potential of cPCR and qPCR for specific, sensitive, and high throughput detection and quantification of $C$. michiganensis subsp. nebraskensis in maize tissues and soil and for improving diagnosis of Goss's wilt. The objective of this work was to capitalize on this potential and to develop and validate assays that meet these technical and biological criteria.

Here, we report widely adaptable and cost-effective techniques for sensitive and specific detection and quantification of the Goss's wilt pathogen $C$. michiganensis subsp. nebraskensis. Using a novel gene target specific to $C$. michiganensis subsp. nebraskensis, both qualitative (cPCR) and SYBR green-based (qPCR) assays were developed for the identification, detection, and enumeration of C. michiganensis subsp. nebraskensis populations in vitro and in maize leaves and complex soil environments. The new assays represent novel and important tools for diagnosis and rapid detection of C. michiganensis subsp. nebraskensis and for applications in epidemiological, plant-microbe interaction, and host resistance research.

\section{MATERIALS AND METHODS}

Source and identity of isolates. The 129 bacterial and fungal isolates used in this study are listed in Table 1 . The collection represented 28 species and 20 genera comprising diverse groups of bacteria and fungi. In total, 78 isolates of $C$. michiganensis were used, including 35 isolates of C. michiganensis subsp. nebraskensis collected at different times and from different geographic locations in the midwestern United States. C. michiganensis subsp. nebraskensis

TABLE 1. Bacterial and fungal isolates used to evaluate specificity of conventional and quantitative polymerase chain reaction (PCR) assays for the detection of C. michiganensis subsp. nebraskensis based on gene CMN_01184

\begin{tabular}{|c|c|c|c|c|c|}
\hline \multirow[b]{2}{*}{ Species } & \multirow[b]{2}{*}{ Host of origin } & \multirow[b]{2}{*}{ No. Isolates } & \multicolumn{2}{|c|}{ CMN_01184 detection } & \multirow[b]{2}{*}{ Source $^{c}$} \\
\hline & & & Conventional PCR ${ }^{\mathrm{a}}$ & $\mathrm{qPCR}^{\mathrm{b}}$ & \\
\hline C. michiganensis subsp. nebraskensis & Maize & 35 & + & + & $1,2,3,4,5,6,7$ \\
\hline C. michiganensis subsp. michiganensis & Tomato & 19 & - & - & 2,8 \\
\hline C. michiganensis subsp. sepedonicus & Potato & 16 & - & - & 2 \\
\hline C. michiganensis subsp. insidiosus & Alfalfa & 2 & - & - & 2 \\
\hline C. michiganensis subsp. tessellarius & Wheat & 2 & - & - & 2 \\
\hline C. michiganensis subsp. phaseoli & Bean & 1 & - & - & 9 \\
\hline C. michiganensis subsp. californiensis & Tomato & 2 & - & - & 4 \\
\hline C. michiganensis subsp. chilensis & Pepper & 1 & - & - & 4 \\
\hline Acidovorax avenae & Crab grass & 1 & - & - & 2 \\
\hline Agrobacterium tumefaciens & Tomato & 2 & - & - & 2 \\
\hline Bacillus cereus & Alfalfa & 1 & - & - & 2 \\
\hline Bacillus subtilis & Environment & 2 & - & - & 2 \\
\hline Burkholderia andropogonis & Maize & 1 & - & - & 10 \\
\hline Brevibacterium lactifermentum & Environment & 1 & - & - & 2 \\
\hline Corynebacterium callunae & Environment & 1 & - & - & 2 \\
\hline Corynebacterium glutamicum & Environment & 1 & - & - & 2 \\
\hline Curtobacterium flaccumfacians & Beet & 3 & - & - & 2 \\
\hline Dickeya zeae & Maize & 2 & - & - & 2 \\
\hline Enterobacter cloacae & Environment & 1 & - & - & 2 \\
\hline Exserohilum turcicum & Corn & 2 & - & - & 11 \\
\hline Fusarium graminearum & Maize & 2 & - & - & 12 \\
\hline Fusarium oxysporum & Soybean & 2 & - & - & 7 \\
\hline Fusarium solani & Potato, soybean & 3 & - & - & 7 \\
\hline Fusarium virguliforme & Soybean & 1 & - & - & 7 \\
\hline Micrococcus luteus & Environment & 1 & - & - & 2 \\
\hline Pantoea agglomerans & Apple & 3 & - & - & 2 \\
\hline Pantoea stewartii & Maize & 3 & - & - & 13,14 \\
\hline Pectobacterium carotovora & Potato & 4 & - & - & 2 \\
\hline Pseudomonas fluorescens & Environment & 2 & - & - & 2 \\
\hline Pseudomonas syringae & Bean, tomato & 5 & - & - & 2 \\
\hline Pythium dissoticum & Soybean & 1 & - & - & 7 \\
\hline Rhizoctonia solani & Soybean & 1 & - & - & 7 \\
\hline Streptomyces griseus & Environment & 1 & - & - & 2 \\
\hline Xanthomonas campestris & Sorghum & 2 & - & - & 2 \\
\hline Xanthomonas spp. & Foxtail & 2 & - & - & 2 \\
\hline Total & & 129 & & & \\
\hline
\end{tabular}

a $+=$ expected $0.67-\mathrm{kb}$ PCR product band; $-=$ no PCR product detected.

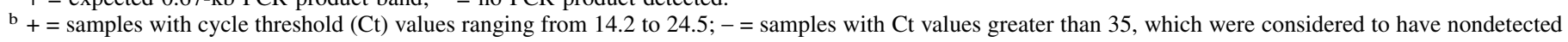
DNA.

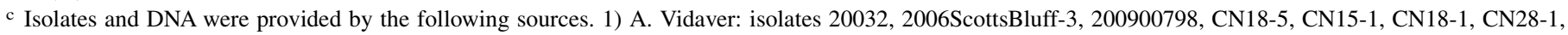
CN30-1, CN72-28, CN76-2, 15-2.0, 15-2.1, 15-2.2, 156-2.0, 156-2.2, 82055, 82055.9, CIGP010, PCC1, CB101.0, CP1.0; 2) C. Ishimaru: isolates CIC056, CIC057, CIC058, CIC059, CIC251, CIC252, FG1-12, LK1-12, MS1-12, MS2-12, CIC190, S26, 10 D, 11J, 6E, ATCC33113, CIC001, CIC003, CIC005, CIC031, CIC077, CIC144, CIC226, CIC227, CIC228, CIC229, S5, TS4, CIC266, CICR1-3, CIA003, CIA004, UW85, CIGP012, ATCC9372, CIC188, CIR294, CIR295, DF13, CIGP008, C9-1, 36740, Lee R-49a, CIP048, B45, CIP054, CIGP013, CIX012, CIX014, CIX001, CIX007, BC1-11A, ED1-11A, PK1-11A, 3404 VS-1, CIP 051, CIG 014, B-37b, C-9-96b, C9-1, Eh75115, A506, 31a, L113-7; 3) C. Bradley: isolates CIC344, CIC345; 4) A. Alvarez: isolates K087, C55, C66, ZUM3936); 5) UMN Plant Disease Clinic: isolates PDC4-11A, PDC4-12, PDC5-11A, PDC5-12, PDC7-12, CIC334; 6) Kasia Kinzer: isolates PP1201420, PP1201528, PP1201626, PP1301135; 7) D. Malvick: isolates 07-071, 07-321, 07-154, 07-373, 07-500, Fv1, MN24JJ, Rh; 8) G. Coaker: isolates AZ28, CA0002, CA498, CASJ009, CFBP7491, CFBP8017, CFBP8019, CMM5, HZII12, NZ2541, Stock20; 9) A. Gonzalez: isolate LPPA982); 10) S. Bissonnette; 11) O. Fajolu: Et race 0, Et race 123N; 12) R. Dill-Macky: isolates 1-1, 14-1-2; 13) S. Miller: isolates Pstew1, Pstew2; 14) G. Beattie: isolates: ES Rif9A. 
isolates were identified via colony morphology and were confirmed using either $16 \mathrm{~S}$ rDNA sequencing, a commercially available Clavibacter michiganensis-specific ImmunoStrip (Agdia Inc., Elkhart, IN) assay, or both, in conjunction with greenhouse pathogenicity studies. C. michiganensis subsp. nebraskensis morphology was characterized by apricot-orange pigmentation, circular colony type, and slow growth (about 5 days). Control isolates for specificity testing were plant pathogens and environmental isolates from agricultural fields, including fungal and bacterial maize pathogens and nonmaize pathogens, fungi, and gram-negative and gram-positive bacteria.

DNA extraction from bacteria and fungi. $C$. michiganensis subsp. nebraskensis isolates were streaked on nutrient broth yeast extract (NBY) agar amended with $\mathrm{MgSO}_{4}(2 \mathrm{mM})$ and cycloheximide $(350 \mu \mathrm{M})$ and were grown at $25^{\circ} \mathrm{C}$ for 5 days (Vidaver 1967). C. michiganensis subsp. nebraskensis cells were harvested using a sterile cotton swab and were incubated in lysozyme buffer $(20 \mathrm{mg} / \mathrm{ml})$ prior to DNA extraction, using a DNeasy blood and tissue kit adapted for gram-positive bacteria as described by the manufacturer (Qiagen, Valencia, CA). Fungal DNA was extracted from mycelia grown on nutrient broth medium. Mycelia were harvested using a sterilized cotton swab and scoopula and were homogenized in a FastPrep instrument (QBiogene, Irvine, CA) and DNA was extracted, using a FastPrep FastDNA kit (MP Biomedicals, Solon, OH), according to the manufacturer's instructions for fungi. Quality and quantity of DNA was determined for all samples using a Nanodrop 2000 spectrophotometer (Thermo Scientific, Waltham, MA). DNA was stored at $-20^{\circ} \mathrm{C}$.

Comparative genomics and primer design. Potential gene targets for specific detection of $C$. michiganensis subsp. nebraskensis were identified by conducting a comparative genomic analysis. The annotated genome of $C$. michiganensis subsp. nebraskensis NCPPB 2581 (National Center for Biotechnology Information [NCBI]: NC_020891) was manually filtered relative to predicted orthology in the genomes of $C$. michiganensis subsp. michiganensis NCPPB 382 (NCBI: NC_009480) and C. michiganensis subsp. sepedonicus ATCC 33113 (NCBI: NC_010407). Putative singletons were discovered via the NCBI sequence alignment search tools BLASTN, BLASTX, and CD-search. Then, putative gene targets for C. michiganensis subsp. nebraskensis detection were filtered relative to nucleic acid sequence conservation with other $C$. michiganensis subspecies. Genes meeting the following criteria were considered putative targets for $C$. michiganensis subsp. nebraskensis detection: i) no nucleic acid or amino acid sequence conservation with other C. michiganensis subspecies and ii) limited nucleic acid sequence conservation with other bacteria and fungi. Based on these analyses, CMN_01184 was identified as a target for specific detection of C. michiganensis subsp. nebraskensis. Predicted orthologs in C. michiganensis were also analyzed for homology in other bacterial species, to identify a target for general detection of all C. michiganensis subspecies. The predicted transporter CMN_00971 (NCBI: CMN_RS04740) was identified in C. michiganensis subsp. nebraskensis NCPPB 2581 and was subjected to BLASTN analysis, with complete query coverage ranging from 96 to $98 \%$ nucleic acid sequence conservation, to evaluate the potential of CMN_00971 (390 bp) for detection of all C. michiganensis subspecies.

Forward and reverse primers were created for specific C. michiganensis subsp. nebraskensis detection based on the nucleic acid sequences of CMN_01184 (NCBI: CMN_RS05785) and CMN_00971 (NCBI: CMN_RS04740). Primers for cPCR were designed manually. Primers for qPCR were created using default parameters with Primer Express software (Applied Biosystems, Foster City, CA). Primers for general bacterial detection and maize DNA quantification were used as previously described (Hernández et al. 2004; Monciardini et al. 2002). All primers used in this study are listed and described in Table 2.

Specificity of cPCR and qPCR assays. Primer set 1184-F/R was tested using cPCR on DNA from 129 isolates of plant- and soilassociated bacteria and fungi (Table 1). The PCR reactions were conducted in a volume of $25 \mu \mathrm{l}$ that contained $5 \mu \mathrm{l}$ of reaction buffer (10x), $10 \mu \mathrm{l}$ of Q-solution (5x), $1 \mu \mathrm{l}$ of dNTP mix (10 mM), $1 \mu \mathrm{l}$ of primer $1184-\mathrm{R}(10 \mu \mathrm{M})$, olne $\mu \mathrm{l}$ of primer $1184-\mathrm{R}(10 \mu \mathrm{M}), 10 \mathrm{ng}$ of DNA template, and $0.25 \mu \mathrm{l}$ of HotStarTaq DNA polymerase (5 units/ $\mu$ l). The Q-solution was included to aid the amplification of GC-rich templates (Qiagen, Valencia, CA). Thermal cycling parameters consisted of $5 \mathrm{~min}$ at $95^{\circ} \mathrm{C}$, followed by 30 to 40 cycles of $45 \mathrm{~s}$ at $94^{\circ} \mathrm{C}, 1 \mathrm{~min}$ at $60^{\circ} \mathrm{C}$, and $1 \mathrm{~min}$ at $72^{\circ} \mathrm{C}$. The reaction was extended for $10 \mathrm{~min}$ at $72^{\circ} \mathrm{C}$. Reactions were carried out using a GeneAmp PCR System 2700 (Applied Biosystems). Production of a predicted 666-bp amplicon was considered confirmation of CMN_01184 and C. michiganensis subsp. nebraskensis in a given sample.

The specificity of primer set 1184-qF2/qR2 for qPCR was evaluated using the same bacterial and fungal isolate collection that was used for the cPCR testing (Table 1). The qPCR reactions were conducted using SYBR green PCR master mix (Applied Biosystems). Reactions were conducted in a volume of $40 \mu \mathrm{l}$, using $0.8 \mu \mathrm{l}$ of primer $1184-\mathrm{qF} 2(10 \mu \mathrm{M}), 0.8 \mu \mathrm{l}$ of primer $1184-\mathrm{qR} 2$ $(10 \mu \mathrm{M})$, DNA template $(50 \mathrm{ng})$, and $20 \mu \mathrm{l}$ of Power SYBR Green PCR master mix $(2 \times)$. Thermal cycling parameters were $2 \mathrm{~min}$ at $50^{\circ} \mathrm{C}$ and $10 \mathrm{~min}$ at $95^{\circ} \mathrm{C}$, followed by 40 cycles of $15 \mathrm{~s}$ at $95^{\circ} \mathrm{C}, 30 \mathrm{~s}$ at $61^{\circ} \mathrm{C}$, and $30 \mathrm{~s}$ at $72^{\circ} \mathrm{C}$. Reactions were carried out using an $\mathrm{ABI}$ 7500 real-time PCR system (Applied Biosystems). Cycle threshold $\left(C_{T}\right)$ values were calculated and were analyzed based on absolute quantification, using StepOnePlus software (Applied Biosystems). $\mathrm{C}_{\mathrm{T}}$ values less than 35 were considered a positive detection response. All samples were run in duplicate on each of two separate amplification plates.

Sensitivity of cPCR and qPCR assays. Sensitivity of primer sets 1184-F/R and 1184-qF2/qR2 was evaluated using DNA template from C. michiganensis subsp. nebraskensis CIC251. Sensitivity was tested with two template sets, one represented CFU of C. michiganensis subsp. nebraskensis and the second represented pure, quantified DNA of C. michiganensis subsp. nebraskensis over a range of concentrations. For the CFU templates, $C$. michiganensis subsp. nebraskensis CIC395 was grown on NBY agar and the cell concentrations were adjusted to $1 \times 10^{8} \mathrm{CFU} / \mathrm{ml}$ (optical density at

TABLE 2. Primers developed and used in this study for conventional polymerase chain reaction (cPCR) and quantitative PCR (qPCR) assays for Clavibacter michiganensis subspecies and controls

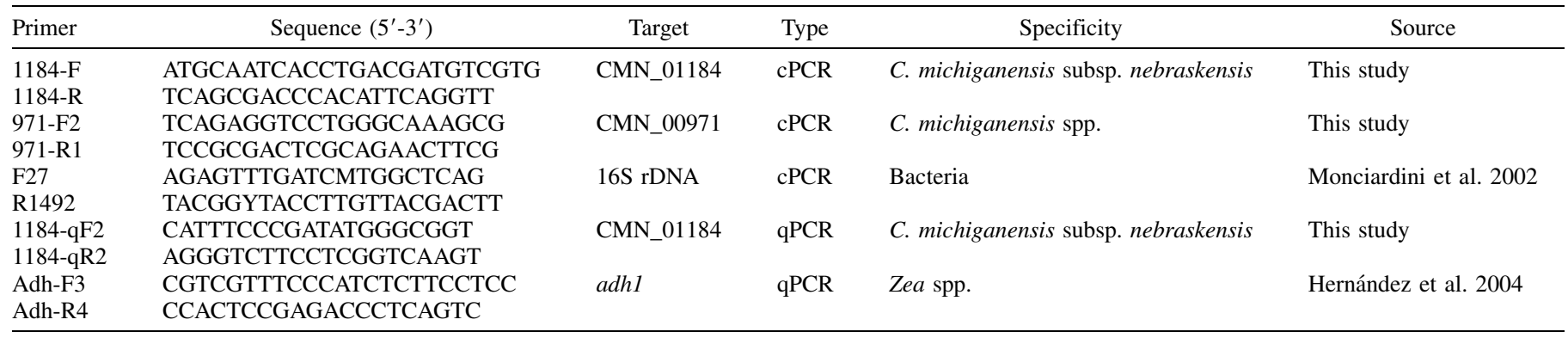


$540 \mathrm{~nm}=0.1)$ in $0.85 \%$ (wt/ $\mathrm{vol}) \mathrm{NaCl}$ suspension, using a spectrophotometer. Ten-fold serial dilutions were made with the cell suspensions and DNA was extracted from each cell suspension as described above. Using the predicted mass of one $C$. michiganensis subsp. nebraskensis chromosome, the $C$. michiganensis subsp. nebraskensis concentration was estimated such that the dilution curve represented one to $1 \times 10^{4} C$. michiganensis subsp. nebraskensis chromosomes per milliliter. For the template set based on pure DNA from C. michiganensis subsp. nebraskensis, a 10-fold serial dilution series was made by diluting a quantified DNA solution to result in concentrations ranging from $3.1 \mathrm{ng}$ to $31 \mathrm{pg}$ per reaction. cPCR and qPCR were conducted with both template sets, as described above. All samples were run in triplicate in three separate reactions.

C. michiganensis subsp. nebraskensis detection in soil and plant samples. To evaluate the specificity of gene target CMN_01184 for detecting C. michiganensis subsp.nebraskensis in field soil samples, C. michiganensis subsp. nebraskensis CIC395 was grown in NBY liquid culture for 2 days and was added to soil as follows. Cell concentration was adjusted via spectrophotometry to $1 \times 10^{7} \mathrm{CFU} / \mathrm{ml}$ and was serially diluted. Sandy loam soil was collected from a maize field in Falcon Heights, MN and $0.25 \mathrm{~g}$ was infested with 1-ml suspensions containing $10^{6}$ to $10^{2} \mathrm{CFU}$ of C. michiganensis subsp. nebraskensis per milliliter. The sampled area had no history of Goss's wilt. An additional soil sample was treated with $1 \mathrm{ml}$ of sterile NBY as an untreated control. DNA was extracted from all samples, using a PowerSoil DNA isolation kit (MoBio Laboratories, Carlsbad, CA). Resultant DNA was used as template for cPCR assays with primer sets 1184-F/R and F27/ R1492, as described above (Monciardini et al. 2002).

To validate the ability of the qPCR primer set $1184-\mathrm{qF} 2 / \mathrm{qR} 2$ to quantify and localize $C$. michiganensis subsp. nebraskensis populations during host infection, maize leaves exhibiting Goss's wilt symptoms were collected from four corn production fields in southern Minnesota. Whole leaves were collected from both healthy and infected corn samples and were stored in plastic bags with paper towels to inhibit moisture development during transportation. In the laboratory, all leaves were stored briefly at $4^{\circ} \mathrm{C}$ prior to sample extraction. Samples were collected, using a cork borer $\left(1.8 \mathrm{~cm}^{2}\right)$, from leaf tissue adjacent to Goss's wilt symptoms. Goss's wilt symptoms included necrosis, chlorosis, and desiccation. Tissue samples were suspended in $1.2 \mathrm{ml}$ of extraction buffer as provided in the FastDNA extraction kit (MP Biomedicals, Solon, $\mathrm{OH}$ ), and DNA was extracted according to the manufacturer's instructions. DNA was stored at $-20^{\circ}$ C. C. michiganensis subsp. nebraskensis infection was confirmed in samples exhibiting Goss's wilt symptoms via isolation on NBY.

The $C$. michiganensis subsp. nebraskensis concentrations in healthy and infected maize leaf samples were quantified using qPCR primer sets 1184-qF2/qR2. The maize reference gene alcohol dehydrogenase 1 was amplified with primer sets Adh-F3/R4. In separate reactions, each sample was quantified for both $C$. michiganensis subsp. nebraskensis and maize DNA concentrations, using 10-fold standard curve dilution series with SYBR green, as described above, via a relative absolute quantification method. C. michiganensis subsp. nebraskensis concentrations were determined as nanograms of $C$. michiganensis subsp. nebraskensis DNA per gram of host DNA, and CFU was calculated based on a standard curve and the predicted chromosome mass of $C$. michiganensis subsp. nebraskensis NCPPB 2581 (NCBI: NC_020891.1).

\section{RESULTS}

Identification of gene targets for specific detection of Clavibacter michiganensis subsp. nebraskensis in-silico. Comparative genomics was used to identify CMN_01184 and CMN_00971 as gene targets for specific and general detection of $C$. michiganensis subsp. nebraskensis and all $C$. michiganensis subsp., respectively. No significant nucleic acid similarity or conserved domains were found for CMN_01184, a predicted hypothetical protein (NCBI:
YP_007685476), supporting the application of CMN_01184 as a specific target for detection of $C$. michiganensis subsp. nebraskensis (Table 2). Thus, CMN_01184 represents a unique and specific target for $C$. michiganensis subsp. nebraskensis detection. The predicted transporter CMN_00971 was identified in C. michiganensis subsp. nebraskensis and orthologs were identified in all C. michiganensis subspecies. No homologs were identified in other bacteria or fungi, supporting the application of CMN_00971 as a target for the detection of all C. michiganensis subspecies (Table 2).

Specificity and inclusivity of CPCR and qPCR assays based on CMN_01184 for detection of $C$. michiganensis subsp. nebraskensis. The cPCR and qPCR assays based on the primers created to target and amplify CMN_01184 were specific for the detection of $C$. michiganensis subsp. nebraskensis. Specificity was confirmed by evaluating a diverse panel of DNA samples from 129 bacterial and fungal isolates (Table 1). No amplification was detected with DNA from 51 isolates of 27 other bacterial and fungal maize pathogens as well as other plant- and soil-associated fungi and bacteria that were tested (Table 1). Neither cPCR nor qPCR assays based on CMN-01184 detected any of the other plant- and soil-associated bacteria and fungi, including the maize-associated pathogens Pantoea stewartii, Dickeya zeae, Burkholderia andropogonis, and Exserohilum turcicum that could confound diagnosis of Goss's wilt. Six actinomycetes were also included in our analysis. These isolates represented five families in the order Actinomycetales, including Curtobacterium flaccumfacians, a relative of $C$. michiganensis subsp. nebraskensis in the Microbacteriaceae family. CMN_01184 amplification was not observed with the other actinomycetes (Table 1).

To further evaluate the specificity of CMN_01184, 43 isolates representing all known subspecies of $C$. michiganensis, including subspecies michiganensis, sepedonicus, insidiosus, and tessellarius as well as the recently identified subspecies phaseoli, californiensis, and chilensis were evaluated (González and Trapiello 2014; Yasuhara-Bell and Alvarez 2015). None of the non-nebraskensis isolates amplified with CMN_01184, confirming that the cPCR and qPCR assays are specific to C. michiganensis subsp. nebraskensis and can distinguish the Goss's wilt pathogen from other $C$. michiganensis subspecies (Table 1). This extensive testing with diverse bacterial and fungal isolates demonstrated the specificity of cPCR and qPCR assays based on CMN_01184 for detection of C. michiganensis subsp. nebraskensis (Table 1). Inclusivity of the cPCR assay was confirmed by the production of the expected 666-bp amplicon corresponding to the target CMN_01184 in all 35 isolates of C. michiganensis subsp. nebraskensis tested from diverse geographical regions (Fig. 1A). All 35 isolates of $C$. michiganensis subsp. nebraskensis tested positive with the qPCR assays, exhibiting $\mathrm{C}_{\mathrm{T}}$ values in the range of 14.2 to 24.5 , further demonstrating high inclusivity for the assays (Table 1).

The PCR assays based on the more general primer set targeting CMN_00971 successfully amplified DNA from all isolates of all C. michiganensis subspecies but did not amplify DNA from any other bacterial or fungal isolates that were tested. In addition, the cPCR assays targeting CMN_00971 amplified Clavibacter DNA when used as the sole assay and when it was multiplexed with the C. michiganensis subsp. nebraskensis-specific assay based on CMN-01184 (Fig. 1A).

Sensitivity of cPCR and qPCR assays. The detection limits of cPCR and qPCR assays based on the CMN_01184 primer set were tested with serially diluted pure $C$. michiganensis subsp. nebraskensis template DNA and DNA from serially diluted viable C. michiganensis subsp. nebraskensis cells. Using pure C. michiganensis subsp. nebraskensis DNA concentrations ranging from $3 \mathrm{ng}$ to $31 \mathrm{pg}$ in cPCR assays, the limit of detection for the cPCR assay was $\leq 31 \mathrm{ng}$ of $C$. michiganensis subsp. nebraskensis DNA (Fig. 1B; Table 3). Using DNA extracted from serial dilutions of $C$. michiganensis subsp. nebraskensis cells, the limit of detection for the cPCR assay was $\leq 100 \mathrm{CFU}$ of $C$. michiganensis subsp. nebraskensis (Table 3 ). To determine sensitivity of the qPCR assay, 
pure DNA was extracted from C. michiganensis subsp. nebraskensis and was diluted and quantified; DNA was extracted from cell suspensions with known numbers of $C$. michiganensis subsp. nebraskensis cells. CMN_01184 transcript abundance was detected with SYBR green and was analyzed using the absolute quantification method. $\mathrm{C}_{\mathrm{T}}$ values ranged from 11.4 for $31 \mathrm{pg}$ of DNA $\left(1 \times 10^{4}\right.$ C. michiganensis subsp. nebraskensis chromosomes) to 27.5 for $3.1 \mathrm{ng}$ of DNA (one predicted chromosome) (Table 3). Thus, the limit of detection for the CMN_1184-based qPCR assay was $\leq 3.1 \mathrm{ng}$ of pure DNA from C. michiganensis subsp. nebraskensis (Table 3). A standard curve representing the average of three replications exhibited an $\mathrm{R}^{2}$ value of 0.99 with reaction efficiency 87.9 (Fig. 2). Efficiency was determined using Applied Biosystems 7500 RealTime PCR software (v2.0.5). It was calculated using the slope of the standard curve regression line and the following equation: Efficiency $=\left(10^{-1 / \text { slope }}-1\right) \times 100$. Sensitivity of the assays in terms of $C$. michiganensis subsp. nebraskensis cell number was also determined using DNA extracted from serial dilutions of C. michiganensis subsp. nebraskensis cultures. The standard curve represented $1 \times 10^{4} \mathrm{CFU} / \mathrm{ml}$, and using the absolute quantification method produced $C_{\mathrm{T}}$ values ranged from 19.9 to 34.1, demonstrating a lower limit of detection of $10 \mathrm{CFU}$ (Table 3).

Detection and quantification of $C$. michiganensis subsp. nebraskensis in infected maize leaves and soil samples. The efficacy and robustness of the cPCR and qPCR assays based on CMN_01184 for detecting and quantifying C. michiganensis subsp. nebraskensis in plant samples were evaluated with maize leaves with symptoms of Goss's wilt and with asymptomatic maize leaf tissue collected at four field locations in Minnesota. Multiplexed cPCR assays based on the C. michiganensis subsp.

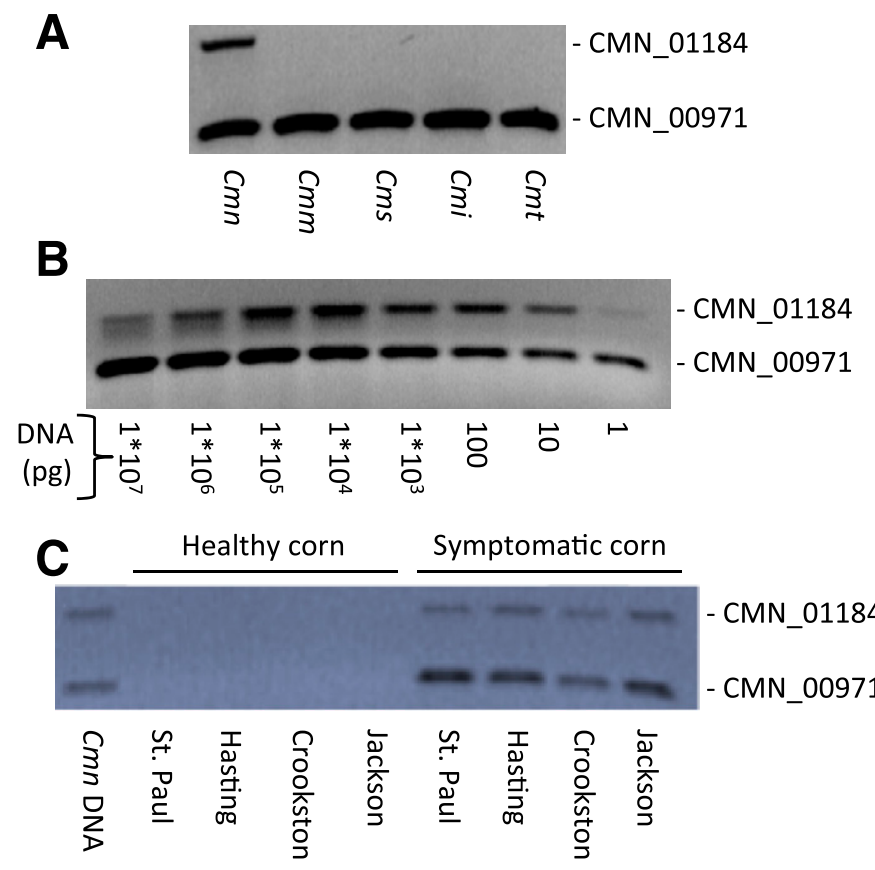

Fig. 1. Specificity and sensitivity of the gene CMN_01184 as a target for in vitro and in planta detection of Clavibacter michiganensis subsp. nebraskensis as determined via conventional polymerase chain reaction (PCR). A, Amplification of CMN_01184 (666 bp, top band) distinguishes C. michiganensis subsp. nebraskensis from other C. michiganensis subspecies, while CMN_00971 (390 bp, lower band) is conserved in all $C$. michiganensis subspecies tested including michiganensis (Cmm), sepedonicus (Cms), insidiosus (Cmi), and tessellarius $(\mathrm{Cmt})$. B, Sensitivity of conventional PCR for detection of pure DNA from C. michiganensis subsp. nebraskensis. The assay based on the CMN_01184 primers detected $\leq 10 \mathrm{pg}$ of $C$. michiganensis subsp. nebraskensis DNA. C, Detection of $C$. michiganensis subsp. nebraskensis from maize tissues exhibiting symptoms of Goss's wilt collected from four Minnesota field locations (right four lanes); no C. michiganensis subsp. nebraskensis was detected in DNA isolated from asymptomatic maize tissue (second through fifth lanes). nebraskensis-specific and C. michiganensis-general primer sets 1184-F/R and 971-F2/R1, respectively, resulted in the production of amplicons only with DNA extracts from symptomatic tissues with both primer sets. No amplicons were produced from the asymptomatic leaf tissue (Fig. 1C). C. michiganensis subsp. nebraskensis was also detected and quantified only in infected maize leaves with the qPCR assay. C. michiganensis subsp. nebraskensis concentrations in maize samples ranged from $5.3 \times 10^{8}$ to $9.3 \times 10^{9} \mathrm{CFU} \mathrm{ml}{ }^{-1}$ per sample (Table 4). These results indicate that the qPCR assay based on CMN_ 01184 can effectively quantify populations of $C$. michiganensis subsp. nebraskensis in infected leaves and measure the development of infection. Further, the microbiome of healthy maize leaves did not create false positives or inhibit detection of $C$. michiganensis subsp. nebraskensis with the PCR assays.

The ability of the PCR assays based on CMN_01184 to detect C. michiganensis subsp. nebraskensis in soil was evaluated with DNA extracted from field soil containing a range of added concentrations of viable C. michiganensis subsp. nebraskensis. Using cPCR, C. michiganensis subsp. nebraskensis was only amplified in the soil samples infested with C. michiganensis subsp. nebraskensis (Fig. 3). The cPCR assay detected $C$. michiganensis subsp. nebraskensis at concentrations as low as $400 \mathrm{CFU}$ per cubic centimeter of soil (Fig. 3 ). To evaluate whether PCR inhibitors in the soil could have influenced amplification, DNA was extracted from soil infested or not with $C$. michiganensis subsp. nebraskensis and the primer set F27/R1492 was used to amplify DNA from all bacteria. A $1.5-\mathrm{kb}$ amplicon indicative of $16 \mathrm{~S}$ bacterial rDNA amplification was produced with all soil samples (Fig. 3). These results demonstrate that PCR assays based on CMN_01184 are robust and specific for detection of $C$. michiganensis subsp. nebraskensis in complex soil environments.

\section{DISCUSSION}

Here, we report the development and validation of a novel DNA target and PCR assays for specific detection and quantification of

TABLE 3. Sensitivity of conventional polymerase chain reaction (cPCR) and quantitative qPCR detection assays based on gene CMN_01184, using pure DNA and whole cells of Clavibacter michiganensis subsp. nebraskensis

\begin{tabular}{|c|c|c|}
\hline \multirow[b]{2}{*}{ Template $^{\mathrm{a}}$} & \multicolumn{2}{|c|}{ PCR detection } \\
\hline & $\mathrm{cPCR}^{\mathrm{b}}$ & $\mathrm{qPCR}\left(\mathrm{C}_{\mathrm{T}}\right)^{\mathrm{c}}$ \\
\hline 31 pg C. michiganensis subsp. nebraskensis & & \\
\hline DNA & + & $11.7 \pm 0.6$ \\
\hline 3.1 pg C. michiganensis subsp. nebraskensis & & \\
\hline DNA & + & $15.8 \pm 0.7$ \\
\hline $\begin{array}{l}0.31 \text { pg C. michiganensis subsp. } \\
\text { nebraskensis DNA }\end{array}$ & + & $19.4 \pm 0.9$ \\
\hline $\begin{array}{l}3.1 \times 10^{-2} \mathrm{pg} \text { C. michiganensis subsp. } \\
\text { nebraskensis DNA }\end{array}$ & + & $23.9 \pm 1.1$ \\
\hline $\begin{array}{l}3.1 \times 10^{-3} \mathrm{pg} \text { C. michiganensis subsp. } \\
\text { nebraskensis DNA }\end{array}$ & - & $27.5 \pm 0.9$ \\
\hline $\begin{array}{l}\text { 10,000 CFU C. michiganensis subsp. } \\
\text { nebraskensis }\end{array}$ & + & $19.9 \pm 0.1$ \\
\hline $\begin{array}{l}\text { 1,000 CFU C. michiganensis subsp. } \\
\text { nebraskensis }\end{array}$ & + & $23.4 \pm 0.0$ \\
\hline $\begin{array}{l}100 \text { CFU C. michiganensis subsp. } \\
\text { nebraskensis }\end{array}$ & + & $26.9 \pm 0.0$ \\
\hline $\begin{array}{l}10 \text { CFU C. michiganensis subsp. } \\
\text { nebraskensis }\end{array}$ & - & $30.5 \pm 0.4$ \\
\hline 1 CFU C. michiganensis subsp. nebraskensis & - & $34.1 \pm 0.7$ \\
\hline
\end{tabular}

${ }^{a}$ Templates represent either quantified pure C. michiganensis subsp. nebraskensis DNA or DNA isolated from quantified serial dilutions of C. michiganensis subsp. nebraskensis culture; $3.1 \times 10^{-3} \mathrm{pg}$ represents the predicted mass of one C. michiganensis subsp. nebraskensis chromosome. $\mathrm{b}+=$ expected $0.67-\mathrm{kb}$ PCR product band; $-=$ no PCR product band detected.

${ }^{c}$ Cycle threshold $\left(\mathrm{C}_{\mathrm{T}}\right)$ values from $\mathrm{qPCR}$ reactions are mean values and standard deviations from samples run in triplicate in three separate reactions. Samples with $\mathrm{C}_{\mathrm{T}}$ values greater than 35 were considered to have nondetectable C. michiganensis subsp. nebraskensis DNA. 
C. michiganensis subsp. nebraskensis. The cPCR and SYBR green-based qPCR assays should be readily accessible and easily adopted in many laboratories for diagnosis of and research on Goss's wilt. Both PCR assays are sensitive tools for detection of C. michiganensis subsp. nebraskensis in plant and soil samples and can distinguish $C$. michiganensis subsp. nebraskensis from other C. michiganensis subspecies in addition to a diverse array of other maize and plant-associated bacteria and fungi.

Using comparative genomic approaches, CMN_01184 was identified in the genome of $C$. michiganensis subsp. nebraskensis NCPPB 2581 as a putative singleton and primers were created for cPCR and qPCR amplification. CMN_01184 was confirmed as a specific target for the detection of $\bar{C}$. michiganensis subsp. nebraskensis by evaluating a collection of 129 bacteria, including 78 isolates of $C$. michiganensis and a diverse array of fungi isolates. These isolates included numerous bacterial and fungal pathogens of maize and the pathogenic $C$. michiganensis subspecies michiganensis, sepedonicus, insidiosus, and tessellarius. The maize fungal pathogens Exserohilum cloacae and Fusarium graminearum were tested along with the widespread maize bacterial pathogens Dickeya zeae, Pantoea stewartii, and Burkholderia andropogonis. PCR assays based on CMN_01184 were specific to C. michiganensis subsp. nebraskensis in all cases, and this gene target was not detected in maize pathogens or other fungi or bacteria or in plant and soil samples tested in this study.

C. michiganensis represents a species of pathogenic bacteria with a diverse and large host range. Since 2014, three new $C$. michiganensis subspecies have been identified, i.e., phaseoli, chilensis, and californiensis. As additional $C$. michiganensis subspecies are confirmed, it is important that detection assays are specific and capable of differentiating between all known subspecies. Currently, the most common strategies for detection of $C$. michiganensis subsp. nebraskensis and diagnosis of Goss's wilt employ agar-based media and commercially available serological assays that cannot distinguish C. michiganensis subsp. nebraskensis from subspecies michiganensis or tessellarius or several other common bacteria found in agricultural fields (Korus 2011). Here, we report, for the first time, novel cPCR and SYBR green-based qPCR assays targeting the gene CMN_01184, which can distinguish C. michiganensis subsp. nebraskensis from all known $C$. michiganensis subspecies as well as a diverse array of other pathogens.

Effective assays for detection and quantification of pathogens must be both specific and sensitive. To demonstrate the sensitivity of our qualitative and quantitative detection assays, $C$. michiganensis subsp. nebraskensis DNA samples and cell suspensions were tested. Our cPCR assay could detect $3.1 \times 10^{-2}$ pg of DNA template and 100 CFU of $C$. michiganensis subsp. nebraskensis. The qPCR assay had a lower limit of detection of $\leq 3.1 \mathrm{ng}$ of pure $C$. michiganensis subsp. nebraskensis DNA template and $10 \mathrm{CFU}$ of $C$. michiganensis subsp. nebraskensis. This level of sensitivity is excellent for diagnosis and for many types of infection, ecological, and epidemiological studies.

C. michiganensis subsp. nebraskensis is a systemic vascular pathogen believed to overwinter in infected maize residues. To directly evaluate the utility of $C$. michiganensis subsp. nebraskensis PCR detection assays based on CMN_01184 for studies of pathogen ecology and epidemiology, C. michiganensis subsp. nebraskensis was detected directly from both multiple-plant and soil samples infected with $C$. michiganensis subsp. nebraskensis. In all cases, C. michiganensis subsp. nebraskensis was detected successfully only from maize tissues exhibiting Goss's wilt symptom and was

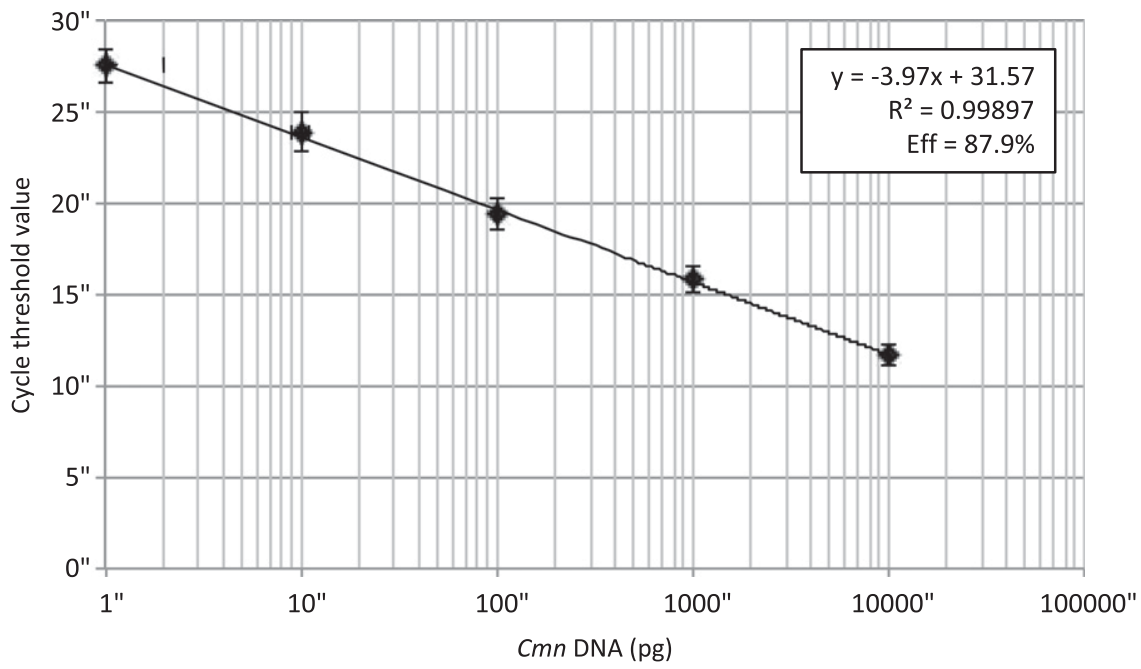

Fig. 2. Standard curve representing quantitative amplification of target gene CMN_01184 in Clavibacter michiganensis subsp. nebraskensis. The relationship between picograms of pure DNA from C. michiganensis subsp. nebraskensis and cycle threshold $\left(\mathrm{C}_{\mathrm{T}}\right)$ values from the quantitative polymerase chain reactions is shown. Trend-line data points represent the mean of three replications. Error bars represent standard deviation.

TABLE 4. Quantification of Clavibacter michiganensis subsp. nebraskensis from infected maize leaf samples ${ }^{\mathrm{a}}$

\begin{tabular}{|c|c|c|c|c|c|}
\hline \multirow[b]{2}{*}{ Location } & \multicolumn{2}{|c|}{ C. michiganensis subsp. nebraskensis } & \multirow{2}{*}{$\frac{\text { Maize }}{\text { DNA (ng) }}$} & \multicolumn{2}{|c|}{ C. michiganensis subsp. nebraskensis/maize } \\
\hline & DNA (ng) ${ }^{b}$ & $\mathrm{CFU} \mathrm{ml^{-1 \textrm {c } }}$ & & DNA (ng/ng) b & Titer $(\mathrm{CFU} / \mathrm{ng})^{\mathrm{b}}$ \\
\hline Martin & 21.58 & $3.0 \times 10^{9}$ & 260.0 & 0.1 & $2.6 \times 10^{4}$ \\
\hline Watonwan & 85.16 & $9.3 \times 10^{9}$ & 71.0 & 1.2 & $3.8 \times 10^{5}$ \\
\hline Rosemount & 12.68 & $5.3 \times 10^{8}$ & 28.3 & 0.4 & $1.4 \times 10^{5}$ \\
\hline
\end{tabular}

${ }^{a}$ Maize leaf samples were collected from four Minnesota field locations, using a quantitative polymerase chain reaction assay based on amplification of CMN_01184 and quantification of the maize reference gene adhl. The adhl primers were developed by Hernández et al. (2004).

${ }^{\mathrm{b}}$ Concentration of $C$. michiganensis subsp. nebraskensis and maize (Zea mays subsp. mays) DNA was determined via absolute quantification, using the total genomic DNA standard curve method in a $40-\mu l$ reaction.

${ }^{c}$ CFU represents a predicted value based on the standard curve of cycle threshold value versus quantity of $C$. michiganensis subsp. nebraskensis DNA and the mass of the C. michiganensis subsp. nebraskensis chromosome (3.13 fg). 
not detected in any asymptomatic maize leaves. Furthermore, to confirm the specificity and sensitivity of CMN_01184, soil samples were infected with $C$. michiganensis subsp. nebraskensis and were tested using our cPCR assay. C. michiganensis subsp. nebraskensis was detected only in soil samples infected with $C$. michiganensis subsp. nebraskensis and our reaction controls amplified general $16 \mathrm{~S}$ bacterial DNA in all soil samples, regardless of $C$. michiganensis subsp. nebraskensis-status, confirming that DNA extractions were successful and PCR inhibitors were not significantly influencing the $\mathrm{PCR}$ reactions. Collectively, these results demonstrate, for the first time, that PCR assays based on CMN_01184 are specific and sensitive tools to detect and quantify $C$. michiganensis subsp. nebraskensis in plant and soil samples. Further, other microbes in maize leaves and field soil do not create false-positive results or interfere with detection of $C$. michiganensis subsp. nebraskensis.

For research on the epidemiology and host-pathogen interactions of $C$. michiganensis subsp. nebraskensis, a precise tool for determining C. michiganensis subsp. nebraskensis population levels in planta during host infection will be valuable. Current strategies for C. michiganensis subsp. nebraskensis quantification are nonspecific and require time-consuming plating techniques susceptible to contamination from other host-associated microbial organisms (Smidt and Vidaver 1986). Using infected maize samples collected from multiple maize production fields, $C$. michiganensis subsp. nebraskensis populations could be quantified and enumerated relative to host DNA concentrations with the new qPCR assay. Importantly, these results validate, for the first time, a molecular approach for the elucidation of $C$. michiganensis subsp. nebraskensis cell concentration, infection, and localization during host infection. The use of $a d h l$ as a maize reference gene accounted for potential PCR inhibitors and differential DNA loss during the isolation process to ensure accurate results.

In summary, we report for the first time a pair of comprehensively tested PCR assays for detection and quantification of C. michiganensis subsp. nebraskensis based on the unique gene target CMN_01184. No previously reported techniques were available for both specific detection and quantification of $C$. michiganensis subsp. nebraskensis that utilized relatively inexpensive and easily adopted cPCR and SYBR green qPCR assays. Thus, we have addressed the need to develop

Template DNA

Detection Primers

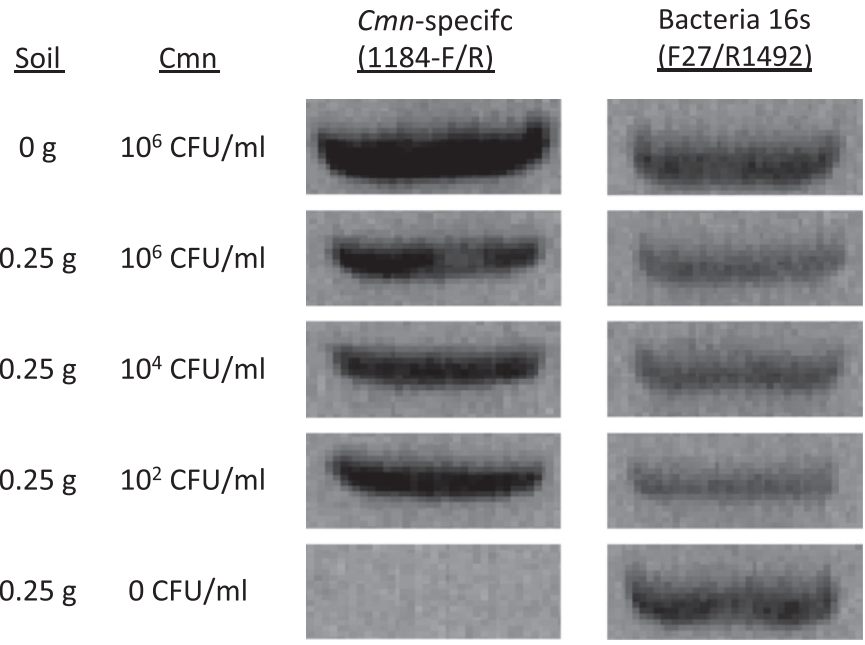

Fig. 3. Conventional polymerase chain reaction (PCR) detection of Clavibacter michiganensis subsp. nebraskensis using CMN_01184-specific primers (Cmnspecific) in field soil samples infested with $0,10^{4}$, or $10^{6} \mathrm{CFU}$ of $C$. michiganensis subsp. nebraskensis per milliliter. Bacterial $16 \mathrm{~S}$ rDNA $(1.5 \mathrm{~kb})$ was also amplified using primer pair F27 and R1492 to check for successful DNA isolations and for the presence of PCR inhibitors. C. michiganensis subsp. nebraskensis was detected only in soil samples containing C. michiganensis subsp. nebraskensis DNA, and $16 \mathrm{~S}$ bacterial rDNA was detected in all soil samples, as expected. and validate a cPCR assay that is a simple, cost-effective tool for rapid diagnosis and other applications, as well as a qPCR assay that is highly sensitive, quantitative, and cost effective and has high throughput potential for diagnosis and research on the epidemiology, ecology, and host-pathogen interactions of C. michiganensis subsp. nebraskensis.

\section{ACKNOWLEDGMENTS}

We thank the Minnesota Corn Research and Promotion Council, Minnesota Rapid Agricultural Response Fund, and the Minnesota Agricultural Experiment Station for providing funding and facilities to conduct this work. We also thank R. Curland for technical assistance with the project and the many generous individuals who donated cultures that were used in this study, as noted in Table 1.

\section{LITERATURE CITED}

Bach, H.-J., Jessen, I., Schloter, M., and Munch, J. C. 2003. A TaqMan-PCR protocol for quantification and differentiation of the phytopathogenic Clavibacter michiganensis subspecies. J. Microbiol. Methods 52:85-91.

Bilodeau, G. J. 2011. Quantitative polymerase chain reaction for the detection of organisms in soil. CAB Rev. Perspect. AgriC. Vet. Sci. Nutr. Nat. Resour. $6: 1-14$.

Eichenlaub, R., and Gartemann, K.-H. 2011. The Clavibacter michiganensis subspecies: Molecular investigation of gram-positive bacterial plant pathogens. Annu. Rev. Phytopathol. 49:445-64.

Friskop, A., Kinzer, K., McConnell, M., Liu, Z., Korus, K., Timmerman, A., and Jackson, T. 2014. First Report of Goss's bacterial leaf blight and wilt of corn caused by Clavibacter michiganensis subsp. nebraskensis in North Dakota. Plant Dis. 98:1739.

Gachon, C., and Saindrenan, P. 2004. Real-time PCR monitoring of fungal development in Arabidopsis thaliana infected by Alternaria brassicicola and Botrytis cinerea. Plant Physiol. Biochem. 42:367-371.

González, A. J., and Trapiello, E. 2014. Clavibacter michiganensis subsp. phaseoli subsp. nov. pathogenic in bean. Int. J. Syst. Evol. Microbiol. 64:1752-1755.

Gross, D. C., and Vidaver, A. K. 1979. A selective medium for isolation of Corynebacterium nebraskense from soil and plant parts. Phytopathology 69:82-87.

Hernández, M., Duplan, M.-N., Berthier, G., Vaitilingom, M., Hauser, W., Freyer, R., Pla, M., and Bertheau, Y. 2004. Development and comparison of four real-time polymerase chain reaction systems for specific detection and quantification of Zea mays L. J. Agric. Food Chem. 52:4632-4637.

Howard, R. J., Harding, M. W., Lynn, J., Kawchuk, L., and Rasmussen, N. 2015. First report of Goss's bacterial wilt and leaf blight on corn caused by Clavibacter michiganensis subsp. nebraskensis in Alberta, Canada. Plant Dis. 99:1034.

Jackson, T. A., Harveson, R. M., and Vidaver, A. K. 2007. Reemergence of Goss's wilt and blight of corn to the central high plains. Plant Health Prog. Published online. doi:10.1094/PHP-2007-0919-01-BR

Jardine, D. J., and Claflin, L. E. 2016. Goss's bacterial wilt and leaf blight. Page 165 in: Compendium of Corn Diseases, 4th Ed., Munkvold, G. P., and White, D. G., eds. APS Press, St. Paul, MN.

Korus, K. A. 2011. Evaluating commercially available diagnostic tests for the detection of Clavibacter michiganensis subsp. nebraskensis, cause of Goss's bacterial wilt and leaf blight in corn. MS thesis. University of Nebraska, Lincoln, NB, U.S.A. Published online. http://digitalcommons. unl.edu/agronhortdiss/22

Lee, I. M., Bartoszyk, I. M., Gundersen-Rindal, D. E., and Davis, R. E. 1997. Phylogeny and classification of bacteria in the genera Clavibacter and Rathayibacter on the basis of 16s rRNA gene sequence analyses. Appl. Environ. Microbiol. 63:2631-2636.

Louws, F. J., Bell, J., Medina-Mora, C. M., Smart, C. D., Opgenorth, D., Ishimaru, C. A., Hausbeck, M. K., de Bruijn, F. J., and Fulbright, D. W. 1998. rep-PCR-mediated genomic fingerprinting: A rapid and effective method to identify Clavibacter michiganensis. Phytopathology 88:862-868.

Malvick, D., Syverson, R., Mollov, D., and Ishimaru, C. A. 2010. Goss's bacterial blight and wilt of corn caused by Clavibacter michiganensis subsp. nebraskensis occurs in Minnesota. Plant Dis. 94:1064.

McCartney, H. A., Foster, S. J., Fraaije, B. A., and Ward, E. 2003. Molecular diagnostics for fungal plant pathogens. Pest Manag. Sci. 59:129-142.

Monciardini, P., Sosio, M., Cavaletti, L., Chiocchini, C., and Donadio, S. 2002. New PCR primers for the selective amplification of 16S rDNA from different groups of actinomycetes. FEMS Microbiol. Ecol. 42:419-429.

Mumford, R., Boonham, N., Tomlinson, J., and Barker, I. 2006. Advances in molecular phytodiagnostics - new solutions for old problems. Eur. J. Plant Pathol. 116:1-19. 
Pastrik, K. H., and Rainey, F. A. 1999. Identification and differentiation of Clavibacter michiganensis subspecies by polymerase chain reaction-based techniques. Phytopathology 147:687-693.

Ruhl, G., Wise, K., Creswell, T., Leonberger, A., and Speers, C. 2009. First report of Goss's bacterial wilt and leaf blight on corn caused by Clavibacter michiganensis subsp. nebraskensis in Indiana. Plant Dis. 93:841.

Schaad, N. W., and Frederick, R. D. 2002. Real-time PCR and its application for rapid plant disease diagnosis. Can. J. Plant Pathol. 24:250-258.

Schroeder, K. L., Okubara, P. A., Tambong, J. T., Levesque, C. A., and Paulitz, T. C. 2006. Identification and quantification of pathogenic Pythium spp. from soils in eastern Washington using real-time polymerase chain reaction. Phytopathology 96:637-647.

Singh, R., Hollier, C., Burks, T., and Frazier, R. 2015. First report of Goss's wilt of corn caused by Clavibacter michiganensis subsp. nebraskensis in Louisiana. Plant Dis. 99:1268.

Smidt, M. L., and Vidaver, A. K. 1986. Differential effects of lithium chloride on in vitro growth of Clavibacter michiganense subsp. nebraskense depending upon inoculum source. Appl. Environ. Microbiol. 52:591-593.

Tambong, J. T., Xu, R., Adam, Z., Cott, M., Rose, K., Reid, L. M., Daayf, F., Briere, S., and Bilodeau, G. J. 2015. Draft genome sequence of Clavibacter michiganensis subsp. nebraskensis strain DOAB 397, isolated from an infected field corn plant in Manitoba, Canada. Genome Announc. 3:e0076815. Published online. http://genomea.asm.org/content/3/4/e00768-15.short

Vidaver, A. K. 1967. Synthetic and complex media for the rapid detection of fluorescence of phytopathogenic pseudomonads: Effect of the carbon source. Appl. Microbiol. 15:1523-1524.
Vidaver, A. K., Gross, D. C., Wysong, D. S., and Doupnik, B. L. 1981. Diversity of Corynebacterium nebraskense strains causing Goss's bacterial wilt and blight of corn. Plant Dis. 65:480-483.

Vidaver, A. K., and Mandel, M. 1974. Corynebacterium nebraskense, a new, orange-pigmented phytopathogenic species. Int. J. Syst. Bacteriol. 24:482-485.

Vincelli, P., and Tisserat, N. 2008. Nucleic acid-based pathogen detection in applied plant pathology. Plant Dis. 92:660-669.

Wysong, D. S., Doupnik, B., and Lane, L. 1981. Goss's wilt and corn lethal necrosis-Can they become a major problem? Pages 104-130 in: Proceedings of the Thirty-Sixth Annual Corn and Sorghum Industry Research Conference. H. D. Loden and D. Wilkinson, eds. American Seed Trade Association, Alexandria, VA.

Wysong, D. S., Vidaver, A. K., Stevens, H., and Stenberg, D. 1973. Occurrence of spread of an undescribed species of Corynebacterium pathogenic on corn in the western corn belt. 1973. Plant Dis. Rep. 57:291-294.

Yasuhara-Bell, J., and Alvarez, A. M. 2015. Seed-associated subspecies of the genus Clavibacter are clearly distinguishable from Clavibacter michiganensis subsp. michiganensis. Int. J. Syst. Evol. Microbiol. 65:811-826.

Yasuhara-Bell, J. H., de Silva, A., Heuchelin, S. A., Chaky, J. L., and Alvarez, A. 2016. Detection of Goss's wilt pathogen Clavibacter michigenensis subsp. nebraskensis in maize by loop-mediated amplification. Phytopathology 106:226-235.

Zaluga, J., Heylen, K., Van Hoorde, K., Hoste, B., Van Vaerenbergh, J., Maes, M., and De Vos, P. 2011. GyrB sequence analysis and MALDI-TOF MS as identification tools for plant pathogenic Clavibacter. Syst. Appl. Microbiol. 34:400-407. 